\title{
Synergizing Mathematical Learning at Higher Institution through Heutagogical Approach
}

\author{
Nor’ain Mohd Tajudin*, Nur Ashikin Suhaimi, Mazlini Adnan, Marzita Puteh \\ Department of Mathematics, Faculty of Science \& Mathematics, Sultan Idris Education University, Malaysia
}

Received February 17, 2020; Revised March 31, 2020; Accepted April 7, 2020

Copyright $\bigcirc 2020$ by authors, all rights reserved. Authors agree that this article remains permanently open access under the terms of the Creative Commons Attribution License 4.0 International License

\begin{abstract}
By the $21^{\text {st }}$ century, education system in the world should prepare its citizens who are not merely knowledgeable but have multidimensional skills in facing globalization and future careers. In this context, various new pedagogical concepts appear: heutagogy, paragogy and cybergogy. In line with this development, educators are urged to implement the pedagogical transformations to use these new concepts. Review of literature shows that there are currently no criteria of heutagogy, paragogy or cybergogy that can be used as a guide in designing teaching and learning, especially in learning mathematics. Therefore, the objective of this study will specifically generate the themes and its' items for heutagogy criteria. Intensive document analyses were done related to teaching and learning models, several Malaysian higher education policy documents, best practices in effective learning environments both locally and abroad in general and in the field of mathematics education, as well as the literature review on aspect of heutagogical approach. The finding of the study revealed six themes for the heutagogical criteria in teaching and learning of mathematics, namely (i)Learner-defined learning contracts, (ii) Learner is the main person in forming a flexible curriculum, (iii) Learner-directed questions, (iv) Flexible and negotiated assessment (v) Reflective practice and, (vi) Collaborative learning. Significantly, these criteria provide a useful guide for instructors or lecturers to critically analyze each of the items and to better support students in learning mathematics for creating human capital with features such as flexible, creative, innovative and good problem solvers to meet the challenges for the future.
\end{abstract}

Keywords Heutagogy, Paragogy, Cybergogy, Education 4.0, Teaching and Learning of Mathematics at Higher Institutions

\section{Introduction}

Nowadays, educators are undertaking responsibility with emerging students who can endure and grow well in the worldwide information and economic growth where students need the ability to innovatively and successfully use skills, capabilities, and competencies to apply in a constantly changing and multifarious new world [1], [2], [3]. The pedagogical, as well as andragogy approaches, are no longer adequate in preparing students to succeed in the workplace, but a more sophisticated and erudite approach is required, whereby students reflect their own learning as well as the processes of learning, and where educators teach students how to teach themselves [4], [5]. Innovative technologies have also generated the need to consider new techniques of teaching approaches, with androgynous less support from some educators as it seems to be out of date with the recent rapid growth of digital learning and media resources in new teaching methods [6].

By the $21^{\text {st }}$ century, education in Malaysia must be prepared to prepare its citizens who are not only knowledgeable but have multidimensional skills in the face of globalization and future careers. All Higher Education Institutions (HEIs) in this country need to make changes by following Industrial Revolution 4.0 because education is so big and challenging. As such, the need for learning opportunities based on information and communication technologies as well as positioning online learning is the latest agenda in education [7], [8]. By 2020, digital portfolios accessible from a variety of devices will enable students to acquire real-world skills and knowledge while also building a future professional career [8]. In this context, a number of new concepts emerge: heutagogy [9], [10], paragogy [11], [12], and cybergogy [13], [14].

In line with this development, the 2018 mandate of the Malaysian Minister of Higher Education also urged educators to implement pedagogical transformations into heutagogy, paragogy and cybergogy. He said that the 
ministry would introduce a policy whereby all HEIs would be allowed to offer 30 percent of the flexible and organic curriculum through these three pedagogies. Literature studies have shown that there are no criteria for heutagogy, paragogy or cybergogy, which can serve as a guide in designing the teaching and learning process [9], [10], especially teaching and learning in mathematics. Therefore, studies on the development and testing of these heutagogy, paragogy and cybergogy criteria should be implemented so that educators, especially in mathematics, understand current and future pedagogy to produce human capital with features such as flexible, creative, innovative and good problem solvers. to face the challenges of the future. Therefore, the focal intention of the study was to develop and test the heutagogy, paragogy and cybergogy criteria for university-level mathematics teaching and learning in Malaysia. Specifically, this article will be focusing on generating themes and items for the criteria of heutagogy for mathematics teaching and learning.

\section{Methodology}

The intensive literature review was done for analyzing teaching / learning models from the theoretical / model / conceptual aspects, several Malaysian policy documents that are related to teaching and learning at Higher Institution as well as best practices in effective learning environments both locally and abroad in general and in the field of mathematics education and in general. This phase will find the themes and items that are relevant to the criteria of heutagogy. There were two strategies that were used to search the pertinent and appropriate literature of the study. These strategies were proposed by [15] and well thought-out as the suitable and well-organized method to ascertain significant literature.

At the first phase, the related electronic databases such as Bernama BLIS, China Knowledge Resource Integrated Database, EBSCO host, Elsevier, Science Direct, Emerald, JSTOR, OVID, ProQuest, Sage Publications, SciVerse, Scopus, Springer Link, Taylor and Francis Online and Wiley Online were cast-off to explore for the relevant articles. The main and important keywords used were heutagogy, twenty-first century teaching and learning, teaching and learning in general and specifically in mathematics subject at higher institution. Furthermore, individual journals on teaching and learning in mathematics education at higher institution were examined individually to find more pertinent and appropriate papers, for example, ASEAN Journal of Teaching \& Learning in Higher Education, Transformative Perspectives and Processes in Higher Education, Journal of Interactive Online Learning, Journal for Research in Mathematics Education, Journal of Further and Higher Education, International Journal of Education and Pedagogy, An International Journal of Complexity and Education,
Eurasia Journal of Mathematics, Science and Technology Education, Global Citizen Digest, Higher Education Management and Policy, Journal of Social Sciences and Humanities, Open Learning: The Journal of Open, Distance and E-Learning British Journal of Educational Technology and others.

In the second phase, the snowballing method was employed where the relevant articles were identified based on the pull-out bibliography of the crucial articles of this review. The literature exploration was steered from May 2018 to January 2020 and restricted to only teaching and learning studies available between 2000 and 2019, which contributed to the limitation of this study. An article was well thought-out for this review if it fulfilled these three criteria: (a) it focused predominantly on teaching and learning in general and specifically in mathematics subject at higher institution, (b) it examined elements of heutagogy in teaching and learning of mathematics or other subjects in general; (c) the investigation was carry out in the venue of higher institutions and among mathematics lecturers. For the intention of this article, only peer-reviewed articles that were published in academic journals were encompassed. Hence, literature reviews, conference proceedings, and theses, were excluded from this review. Duplication, indistinguishable and identical publications that disinterested was removed. The articles were selected for relevance, essentially based on the title, abstracts, and keywords.

As mentioned above, an intensive literature review was also done for analyzing teaching/learning models from the theoretical/model/conceptual aspects. The theories in this study are based on the theory underlying mathematical learning and teaching, which is mathematical understanding concept by Skemp [16]) and Ausubel [17]'s learning theory. The importance of conceptual understanding in mathematical learning provides a clear picture of a conceptual relationship. Proper teaching of mathematics by educators can facilitate the process of understanding mathematical concepts [18]. Thus, the Skemp theory [16] of understanding explored students into two types of instrumental-related understanding and Ausubel's [17] learning theory explored students' learning of mathematics through exploration.

Several documents also have been reviewed in the context of the development of higher education in Malaysia, and have extended this study in terms of the integration and relevance of the higher education system including strengthening the quality and competitiveness of higher education Institutions. The followings are the strategic initiatives for the development of first-class human capital in Malaysia: (i) Malaysian Education Development Plan (Higher Education) 2013-2025 (ii) National Higher Education Strategic Plan 2020 (iii) National Transformation 50 (iv) Vision 2020 (v) 11th Malaysian Plan (2016-2020) (vi) Future Ready Curriculum for Malaysian Public University. 


\section{Findings and Discussion}

This section will discuss the findings based on teaching / learning models from the theoretical/model/conceptual aspects, several Malaysian policy documents that are related to teaching and learning at higher institution as well as best practices in effective learning environments both locally and abroad in general and in the field of mathematics education and in general.

No articles were established on the theme of heutagogy in mathematics teaching. However, this analysis revealed a total of 16 articles on themes related to heutagogy in teaching and learning of mathematics as well as in general subjects at higher education institutions circulated and published between 2000 and 2019 (Table 2). These articles were issued in several multidisciplinary journals linked with mathematics education, science education, general education, and technology. One paper was published in 2016, 2014, 2009. 2207, 2006 and two articles in 2012, three articles in 2013, and one article in 2016. During the exploration and search epoch for this reviewed article, there was no paper being published from 2017 to 2019. Nevertheless, this amount is predictable to rise as the area of the research is growing acceptance globally. The articles which were swotted in this study discovered themes and items that generated the heutagogical approach in the teaching and learning of mathematics. Table 1 showed that there are six main themes: (i)Learner-defined learning contracts in teaching and learning of mathematics, (ii) Learner is the main person in forming flexible curriculum in teaching and learning of mathematics, (iii)
Learner-directed questions in the teaching and learning of mathematics, (iv) Flexible and negotiated assessment in the teaching and learning of mathematics. (v) Reflective practice in teaching and learning of mathematics and, (v) Collaborative learning in teaching and learning of mathematics. Most of the articles discussed each of the terms of the principles of heutagogy and the theme on "learner-defined learning contracts in teaching and learning of mathematics" was the most that can be found.

From the analyses of the educational policy perspective, it was found that the documents had outlined four key policies that support the development of the heutagogical approach, which are the National Philosophy of Education, Malaysian Education Development Plan (Higher Education) 2015-2025, the Future of Curriculum Philosophy and the National Higher Education Strategic Plan 2020. The Malaysian higher education transformation has explored a more flexible and interactive higher learning ecosystem including first-class human capital that is capable of using proactive, creative, innovative and technical skills [19] and manages to address changing global environment to improve quality live and contribute to the well-being and wealth of the nation and the world [20]; knowledgeable, able to spark ideas, creativity and innovation generated from the research, absorption, and adaptation of existing knowledge from around the world that can form the basis of the progress of the nation and society at large; and the consolidation of the forces of diversity that strengthen unity, national identity, social justice, national well-being and universal society [21].

Table 1. Themes of Heutagogy Criteria

\begin{tabular}{|c|c|c|c|c|c|c|c|}
\hline \multicolumn{2}{|c|}{ Author } & $\begin{array}{c}\text { Learner-defined } \\
\text { learning } \\
\text { contracts }\end{array}$ & $\begin{array}{l}\text { Learner is the } \\
\text { main person in } \\
\text { forming flexible } \\
\text { curriculum. }\end{array}$ & $\begin{array}{l}\text { Learner-directed } \\
\text { questions }\end{array}$ & $\begin{array}{c}\text { Flexible and } \\
\text { negotiated } \\
\text { assessment }\end{array}$ & $\begin{array}{c}\text { Reflective } \\
\text { practice }\end{array}$ & $\begin{array}{c}\text { Collaborative } \\
\text { learning }\end{array}$ \\
\hline 1 & [10] & $\mathrm{x}$ & $x$ & $\mathrm{x}$ & $\mathrm{x}$ & $x$ & $\mathrm{x}$ \\
\hline 2 & [22] & $\mathrm{x}$ & & $\mathrm{x}$ & $\mathrm{x}$ & $x$ & \\
\hline 3 & [9] & $\mathrm{x}$ & $\mathrm{x}$ & & $\mathrm{x}$ & $\mathrm{x}$ & $\mathrm{x}$ \\
\hline 4 & [23] & $\mathrm{x}$ & $x$ & & & & $\mathrm{x}$ \\
\hline 5 & [6] & $\mathrm{x}$ & $\mathrm{x}$ & & & & $\mathrm{x}$ \\
\hline 6 & [24] & & $x$ & & $x$ & $x$ & $x$ \\
\hline 7 & [25], [ 26] & $\mathrm{x}$ & $\mathrm{x}$ & & & $\mathrm{x}$ & $\mathrm{x}$ \\
\hline 8 & [27] & $\mathrm{x}$ & $\mathrm{x}$ & & & & $\mathrm{x}$ \\
\hline 9 & [28] & $\mathrm{x}$ & & $\mathrm{x}$ & $\mathrm{x}$ & $\mathrm{x}$ & \\
\hline 10 & [29] & $\mathrm{x}$ & $\mathrm{x}$ & & & $x$ & \\
\hline 11 & [30] & & & & & $\mathrm{x}$ & \\
\hline 12 & [31] & $\mathrm{x}$ & $\mathrm{x}$ & & & & \\
\hline 13 & [32] & $\mathrm{x}$ & $\mathrm{x}$ & $\mathrm{x}$ & & & \\
\hline 14 & [33] & $\mathrm{x}$ & $x$ & $\mathrm{x}$ & & & \\
\hline 15 & [34] & $\mathrm{x}$ & & & & & \\
\hline
\end{tabular}


The study also analyzed the educational program documents such as the Future Philosophy of Philosophy that also highlighted the twenty-first century approach to teaching and learning [36]. This curriculum is in line with the acceleration of automation with the accelerated internet network and the emergence of physical processes such as cyber-physical to be implemented in the teaching and learning of higher education [37]. Students will be prepared with mastery of new technologies that utilize automation, analysis, and Big Data, simulation, system integration and Robotic and Cloud [36], [37].

Based on the above several Malaysian policy documents and documents in the context of the development of higher education in Malaysia, this study had revealed several items that are related to all six themes that have been mentioned earlier, which upkeep the centeredness of the learner in a heutagogical approach. Table 2 indicates all the items of each theme.

a) Learner-defined learning contracts in teaching and learning of mathematics

It was argued that learning agreements or contracts sustenance students in outlining and shaping their learning pathways [38]. For example, these agreements are such as delineate what will be studied in the course (e.g., area of study, the scope of the study), the method of how it will be learned (e.g., teaching and learning approaches, learning activities), and what will be evaluated and how it will be evaluated. In this situation, the instructors or the lecturers always inspire and stimulate students giving ideas on how the content in the course will be studied (e.g., the method, strategies and techniques of teaching and learning, learning activities, encourage student's suggest what will be assessed or evaluated in the teaching and learning processes as well as they let student states how the content learned will be assessed.

b) The learner is the main person in forming a flexible curriculum in teaching and learning of mathematics

In a self-determined learning situation, the learner is the main person in forming a flexible curriculum, which is outlined by the students themselves. These indicate that the learners would be able to form their learning pathways and instructors or lecturers assist as the guidance in a student's learning pathways [26], [39]. The curriculum is flexible in this context means that the actions learning always takes into consideration the students' negotiation, which is always adapted and evolved according to their needs [26], [39]. Furthermore, [26] emphasized that the students will always consulted and negotiated about what, when, how, why and what upper level they need to take their learning paths. In this situation of learning environment, the instructors or lecturers always upkeep students to contextualize concepts, knowledge and new understanding which emphasiszed on relational understanding rather than just instrumental understanding [40]. c) Learner-directed questions in the teaching and learning of mathematics

In this heutagogical approach environment, the directed questions posed by the learners and the argument and dialogue that were consequences from these questions will be a guide to the learners and could be function as tools for assisting learners in making sense of the course content, would help to clarify the ideas and facts, as well as stimulate in promoting individual and group reflection [34], [41]. According to [38], One of the great obstacles that heutagogical approach practitioners face is managing students to delineate self-directed questions as well as, as the course creators, they need to be creative enough to have learners ask questions about the universe they inhabit. In this environment, the instructors always guide students to define self-directed questions, encourage students to ask questions about course contents, make sure that students bring clarity to ideas of course content, guide students how to be discerning about ideas and contents of the course, promote students' individual and group reflection, and assign tasks that encourage students to discuss in helping them make sense of the course contents.

d) Flexible and negotiated assessment in the teaching and learning of mathematics

In heutagogy, [9] stated that the learner is involved making their own assessments. Several researchers have elucidated that assessments conducted in consultation and negotiation with students have enhanced students' motivation and engagement in the learning process, and students feel less threatened by the control of the lecturer during the learning processes. [24], [26], [29], [39]. According to [42], the students' learning agreements or contracts can be employed as a method of integrating negotiation into the assessment process. The assessment implemented in the learning should be a measurable form for assessing content comprehension. The use of rubrics is also highly recommended in guiding students to assess their own assessment learning process, for instance by evaluating "discussion skills, quality of work, outcomes, collaboration, academic soundness and knowledge of material" [27, p. 186]. In this learning situation, instructors or lecturers will make sure that the students engage in planning their assessments as well as integrate students' negotiation into the assessment process with the employment of the learning agreements or contracts. This will take into consideration the various techniques of assessing understanding of course contents, the use of rubrics in helping student for their self-assessment process, such as by evaluating their discussion skills, and allow students' negotiation and consultation when to evaluate them.

\section{e) Reflective practice in teaching}

[26] stated that one of the key features of the 
heutagogical approach is that lecturers practice a reflective practice. It is an important learning skill which means knowing how an individual student learns. The heutagogy approach considers past learning experiences and how their experiences reflect the potential for transformative learning growth [9]. Reflective journals [43], action research [24] and on-going, personalized assessment and feedback are some activities that can be blended and fused in the learning processes to upkeep reflective practice. Thus, in this learning environment, instructors would incorporate reflective learning journal for students to mirror upon the contents of the course and discussion and discover new ideas, concepts and facts, form a continuous practice of reflection in the teaching and learning process and carry out action research to provide students with opportunities to explore and research real-life scenarios, which can help prepare them for future work. The instructors also can provide personalized assessments to encourage the students in raising his or her practice of reflective, give feedback support to students in developing the self-direction capability, and build up the elements of reflective practice demonstrated by students. They also would practice double-loop teaching and learning [41], as well as facilitate metacognition teaching and learning. f) Collaborative learning in teaching and learning of mathematics

An important component of the heutagogical classroom is collaborative learning. In these learning situations, students study together, collaborating in a collaborative space to explain a shared concept, fact or idea, and thinking together about how they learn and how to apply those ideas in their practice [24]. [34] proposes a team-based approach to community practice, where learning is primarily about the learning process and how students learn. Knowledge sharing must be comprehensively implemented and this can be achieved by encouraging students to constantly share resources and information [30]. In this situation, lecturers need to ensure that students work together in a collaborative space to create this positive sharing practice. This team-based approach is strongly recommended to be implemented in the heutagogical classroom so that the learning focus is on the learning process and how students learn. Furthermore, they also encourage students to share resources and information on the course contents and use social media to encourage students' collaborative learning. In today's technology advancement, they also should apply e-learning so that the student can be collaborators in their learning.

Table 2. Items of each Heutagogy Criteria

\begin{tabular}{|c|c|}
\hline \multicolumn{2}{|r|}{ HEUTAGOGY CRITERIA } \\
\hline \multicolumn{2}{|r|}{ A. Learner-defined learning contracts in teaching and learning of Mathematics } \\
\hline 1. & students determine their individual learning paths. \\
\hline 2. & students define what will be learned in the course (e.g., scope) \\
\hline 3. & $\begin{array}{l}\text { encourage student gives ideas on how the content in the course will be learned (e.g., teaching and learning approaches, } \\
\text { learning activities), }\end{array}$ \\
\hline 4. & encourage students suggest what will be assessed in the process of teaching and learning. \\
\hline 5 & let student states how the content learned will be assessed. \\
\hline \multicolumn{2}{|r|}{ B. Learner is the main person in forming a flexible curriculum in teaching and learning of Mathematics } \\
\hline 6 & encourage students to create their learning map. \\
\hline 7 & support students to contextualize concepts, knowledge and new understanding. \\
\hline 8 & serve as the compass in student's learning map. \\
\hline 9 & want students to negotiate action learning according to their needs. \\
\hline 10 & give students to negotiate how, when, where and what upper (rather than minimal) level they want to take their learning. \\
\hline \multicolumn{2}{|r|}{ C. Learner-directed questions in the teaching and learning of Mathematics } \\
\hline 11 & guide students to define self-directed questions. \\
\hline 12 & encourage students to ask questions about course contents. \\
\hline 13 & make sure that students bring clarity to ideas of course content. \\
\hline 14 & guide students how to be discerning about ideas and contents of the course. \\
\hline 15 & promote students' individual reflection. \\
\hline 16 & promote students' group reflection. \\
\hline 17 & assign tasks that encourage students to discuss in helping them make sense of the course contents. \\
\hline \multicolumn{2}{|r|}{ D. Flexible and negotiated assessment in the teaching and learning of Mathematics } \\
\hline 18 & make sure students involve in designing their assessments. \\
\hline 19 & incorporate students' negotiation into the assessment process through the use of learning contracts. \\
\hline
\end{tabular}




\begin{tabular}{|l|l|}
\hline 20 & include measurable forms of assessing understanding of course contents. \\
\hline 21 & use rubrics in guiding students in their self-assessment process, for example by assessing their discussion skills. \\
\hline 22 & consider students' negotiation when to assess them. \\
\hline \multicolumn{2}{|l|}{ E. Reflective practice in teaching and learning of mathematics } \\
\hline 23 & $\begin{array}{l}\text { incorporate reflective leaning journal for students to reflect upon the course contents and discussion and explore new } \\
\text { ideas. }\end{array}$ \\
\hline 24 & establish an on-going practice of reflection in the process of teaching and learning. \\
\hline 25 & $\begin{array}{l}\text { assign action research and/or research tasks to gives students opportunity to experiment with real-world scenarios, } \\
\text { which can help prepare them for the professional workplace. }\end{array}$ \\
\hline 26 & provide personalized assessments to support the students in developing his or her reflective practice. \\
\hline 27 & give feedback support to students to develop the capability of self-direction. \\
\hline 28 & reinforce examples of reflective practice demonstrated by students. \\
\hline 29 & practice double-loop teaching and learning. \\
\hline 30 & facilitate metacognition teaching and learning. \\
\hline 32 & $\begin{array}{l}\text { ensure students work together in a collaborative space to create shared meaning and to reflect and think about how they } \\
\text { learned and how to apply it in practice }\end{array}$ \\
\hline 32 & $\begin{array}{l}\text { recommend team-based approaches to learning where the focus of learning is primarily on the learning process and how } \\
\text { students learn. }\end{array}$ \\
\hline 32 & encourage students to share resources and information of the course contents. \\
\hline 35 & use social media to encourage students' collaborative learning. \\
\hline & apply e-learning so that the student can be collaborators in their own learning. \\
\hline
\end{tabular}

\section{Conclusions}

From intensive literature review and document analyses, six themes for the heutagogical criteria had been found, namely. (i)Learner-defined learning agreements or contracts in teaching and learning of mathematics, (ii) Learner is the main person in forming flexible curriculum in teaching and learning of mathematics, (iii) Learner-directed questions in the teaching and learning of mathematics, (iv) Flexible and negotiated assessment in the teaching and learning of mathematics. (v) Reflective practice in teaching and learning of mathematics and, (v) Collaborative learning in teaching and learning of mathematics. For each theme, several items could explain the themes in detail to inform the instructors of the ways to implement the heutagogical approach in class. Significantly, this research will be developing the heutagogy criteria to guide all university-level mathematics lecturers in the current and future teaching and learning processes. The criteria are also to ensure that the quality of lecturers is in line with the recommendations of the Ministry of Higher Education which want lecturers to transform pedagogy into education 4.0 and be consistent with the aspirations of Malaysian Education Development Plan (Higher Education) 2015-2025 that emphasize $21^{\text {st }}$ century teaching and futuristic teaching. This study fulfills the mandate of the ministry to implement heutagogy approach in teaching and learning of mathematics in Malaysian institutions of higher learning. The themes and related items as in Table 2 provide a useful guide for instructors or lecturers to critically analyze each of the items and to better support students in learning mathematics using the heutagogy criteria to understand the present and future pedagogy for creating human capital with features such as flexible, creative, innovative and good problem solvers to meet the challenges for the future. Further research on this area needs to be done, namely validating the heutagogy criteria using the experts' validity procedures as well as using the factorial analysis method of the principal axis to reduce items that will summarize the important information for each theme.

\section{Acknowledgments}

We extend our gratitude to Ministry of Education Malaysia for providing the funds under the Fundamental Research Grant Scheme (Code: FRGS/1/ 2018/SS109/ UPSI/02/31) and Sultan Idris Education University, for providing the official approval that enable us to do the research.

\section{REFERENCES}

[1] The World Bank. (2003). World Development Report 2004 (Overview): Making Services Work for Poor People. World Bank.

[2] Kuit, J. A. \& Fell, A. (2010). Web 2.0 to Pedagogy 2.0: A Social-Constructivist Approach to Learning Enhanced by Technology. In Critical Design and Effective Tools for 
E-Learning in Higher Education: Theory Into Practice. IGI Global.

[3] Siti Hamisah, T. \& Marlia, P. (2018). Higher Education 4.0: Current Status and Readiness in Meeting the Fourth Industrial Revolution Challenges. Putrajaya: Kementerian Pendidikan Tinggi.

[4] Peters, O. (2004). Distance education in transition New trends and challenges (4th ed., Volume 5). Oldenburg, Germany: Bibliotheks- und Information system der Universität Oldenburg.

[5] Kamenetz, A. (2010). Edupunks, edupreneurs, and the coming transformation of higher education. Canada: Chelsea Green Publishing Company.

[6] Wheeler, S. (2011, July 8). Learning with e’s: Digital age learning. [Blog post.] Retrieved from http://steve-wheeler.blogspot.com/2011/07/digital-age-lear ning.html

[7] Muresan, M. (2014). Using Cybergogy and Andragogy Paradigms in Lifelong Learning. 5th World Conference on Educational Sciences - WCES 2013 (pp. 4722-4726). Romania: Procedia - Social and Behavioural Sciences 116.

[8] Lindsay, L. (2017). Transformation of Teacher Practice Using Mobile Technology with One-To-One Classes: M-Learning Pedagogical Approaches. British Journal of Educational Technology, 47(5), 883-892.

[9] Blaschke, L. M. (2012). Heutagogy and Lifelong Learning: A Review of Heutagogical Practice and Self-Determined Learning. Oldenburg University and University of Maryland University College (UMUC).

[10] Hase, S. (2016). Self-determined learning (heutagogy): Where have we come since 2000? Special Edition of Southern Institute of Technology Journal of Applied Research. URL: from: https://www.sit.ac.nz/Portals/0/upload/documents/sitjar/He utagogy\%20-\%20One.pdf.

[11] Corneli, J. \& Danoff, C. (2011). Paragogy. proceedings of the 6th Open Knowledge Conference. Retrieved from http://ceur-ws.org/Vol-739/paper_5.pdf

[12] Lee, Y. \& Rofe, J.S. (2016) Paragogy and flipped assessment: Experience of designing and running a MOOC on research methods. Open Learning: The Journal of Open, Distance and e-Learning31(2): 116-129.

[13] Wang, M. J. \& Kang, J. (2006). Cybergogy of Engaged Learning Through Information and Communication Technology: A Framework for Creating Learner Engagement. New York: Springer Publishing.

[14] Wang, M. J. (2008). Cybergogy for Engaged Learning. Journal of Open and Distance Education in China, 14(2), $14-22$.

[15] Page, D. (2008). Systematic Literature Searching and the Bibliographic Database Haystack. The Electronic Journal of Business Research Methods, 6(2), 171-180.

[16] Skemp, R. R. (1976). Relational understanding and instrumental understanding. Mathematics Teaching, 77, 20-26.

[17] Ausubel, D. P. (1963). The psychology of meaningful verbal learning. New York: Grune \& Stratton.

[18] Yahaya, A., Elanggovan, A., \& Savarimuthu, L. M. (2010) Kepentingan Kefahaman Konsep dalam Matematik. Malaysia: Universiti Teknologi Malaysia.

[19] Kementerian Pengajian Tinggi. (2011). Amanat Menteri Pengajian Tinggi Malaysia, "Pengajian Tinggi Ke Arah Transformasi Negara". Kuala Lumpur: Kementerian Pengajian Tinggi.

[20] Kementerian Pengajian Tinggi. (2015). Pelan Pembangunan Pendidikan Malaysia 2015-2025 (Pengajian Tinggi). Kuala Lumpur: Kementerian Pendidikan Malaysia.

[21] Kementerian Pengajian Tinggi. (2004). Pelan Strategik Pengajian Tinggi Negara 2020. Kuala Lumpur: Kementerian Pengajian Tinggi.

[22] Herie, M. (2013). Andragogy 2.0? Teaching and Learning in the Global Classroom: Heutagogy and Paragogy. Global Citizen Digest, (pp. 2(2):8-14).

[23] Anderson, T. (2010). Theories for learning with emerging technologies. In G. Veletsianos (Ed.), Emerging technologies in distance education. Edmonton: Athabasca University Press. Retrieved from http://www.aupress.ca/books/120177/ebook/02 Veletsianos_2010-Emerging_Technologies_in_Dista nce_Education.pdf

[24] Canning, N. \& Callan, S. (2010). Heutagogy: Spirals of Reflection to Empower Learners in Higher Education. Reflective Practice, 11(1), 71-82.

[25] Hase, S. \& Kenyon, C. (2001). Moving From Andragogy to Heutagogy: Implications for Vocational Education Technology (VET). Proceedings of Research to Reality: Putting VET Research to Work: Australian Vocational Education and Training Research Association (AVETRA). Adelaide: Crows Nest.

[26] Hase, S. (2009). Heutagogy and e-learning in the workplace: Some challenges and opputunities. Impact: Journal of Applied Research in Workplace E-learning , 4(1), 111-119.

[27] Eberle, J.H. (2013). Lifelong learning in S. Hase, \& C. Kenyon, C.(eds,) Self-determined learning: heutagogy in action, London: Bloomsbury, 145-158.

[28] Hase, S. (2014). An introduction to self-determined learning (heutagogy) in L. M Blaschke, C. Kenyon \& S. Hase, S. (eds.) Experiences in self-determined learning, Amazon,1-19

[29] Ashton, J., \& Elliott, R. (2007). Juggling the balls - study, work, family and play: Student perspectives on flexible and blended heutagogy. European Early Childhood Education Research Journal, 15(2), 167-181.

[30] Ashton, J., \& Newman, L. (2006). An unfinished symphony: 21st century teacher education using knowledge creating heutagogies. British Journal of Educational Technology, 37(6) 825-840. DOI: 10.1111/j.1467-8535.2006.00662.x

[31] Parslow, G. M. (2010). Commentary: Heutagogy, The Practice of Self-Learning. Biochemistry and Molecular Biology Education, 38(2), 121.

[32] Hurley, J \& Neilson, G 2013, 'Workplace learning for 
nurses', in S Hase \& C Kenyon (eds), Self-determined learning: heutagogy in action, Bloomsbury Academic, London, UK, pp. 85-98. ISBN: 9781441142771

[33] Bhoyrub, J., Hurley, J., Nielson, G. R., Ramsay, M., \& Smith M. (2010). Heutagogy: An Alternative Practice Based Learning Approach. Journal of Nurse Education in Practice, 10(6); 322-326.

[34] Kenyon, C., \& Hase, S. (2010). Andragogy and heutagogy in postgraduate work. In T. Kerry (Ed.), Meeting the challenges of change in postgraduate education. London: Continuum Press.

[35] Kerry, T. (2013). Applying the principles of heutagogy to a postgraduate distance-learning program. In S. Hase \& C. Kenyo (Eds. ), Self-determined learning: Heutagogy in action. London: Bloomsbury Academic.

[36] Rose Alinda, A., Ali, S., Norris, S. A., Suraya, M. \& Nazmona, M. A. (2018). Framework of Malaysia Higher Education for Fourth Industrial Revolution. Putrajaya: Kementerian Pendidikan Tinggi.

[37] Mohd Fairuz, M. Y. (2017). Revolusi Perindustrian Keempat, Industri 4.0 (IR 4.0). Kuala Lumpur: Jabatan Perangkaan Malaysia .

[38] Kenyon, C., \& Hase, S. (2001). Moving from andragogy to heutagogy in vocational education. Retrieved from http://www.avetra.org.au/abstracts_and_papers_2001 / Hase-Kenyon_full.pdf

[39] Hase, S. \& Kenyon, C. (2007). Heutagogy: A child of complexity theory. An International Journal of Complexity and Education, 4(1), 111-119.

[40] Hiebert, J., \& Carpenter, T.P. (1992). Learning and teaching with understanding. In: D. A. Grouws (Ed.), Handbook of research on mathematics teaching and learning (pp. 65-92). New York: Macmillan. [41]; Eberle, J. (2009, October). Heutagogy: What your mother didn't tell you about pedagogy and the conspetual age. Proceedings from the 8th Annual European Conference on E-learning, pp. 29-30.

[41] Kenyon, C., \& Hase, S. (2001). Moving from andragogy to heutagogy in vocational education. Retrieved from http://www.avetra.org.au/abstracts_and_papers_2001/Hase -Kenyon_full.pdf

[42] Hase, S. (2009). Heutagogy and e-learning in the workplace: Some challenges and opputunities. Impact: Journal of Applied Research in Workplace E-learning , 4(1), 111-119.

[43] Blaschke, L.M., \& Brindley, J. (2011). Establishing a foundation for reflective practice: A case study of learning journal use. European Journal of Open, Distance, and E-Learning (EURODL), Special Issue. Retrieved from http://www.eurodl.org/materials/special/2011/Blaschke_Br indley.pdf 